\title{
STUDIES IN SECOND LANGUAGE ACQUISITION
}

\section{Notes for Contributors}

Contributions. Contributions are welcomed from all countries. They should be written in English. All articles should be sent to:

Albert Valdman, Editor

Studies in Second Language Acquisition

1105 E. Atwater

Indiana University

Bloomington, IN 47405, U.S.A.

Manuscripts. SSLA requires that all submissions conform to the requirements of the Publication Manual of the American Psychological Association (Third Edition), which can be obtained from the American Psychological Association, Order Department, P.O. Box 2710, Hyattsville, MD 20784. It is also available in many bookstores and libraries.

All manuscripts should be submitted in four copies, three copies for book reviews. No materials will be returned to authors unless postage is provided. Contributors should keep a copy of the manuscript; the original manuscript will not be included with the page proof. All submissions must be typewritten, double-spaced, on standard-size paper, $81 / 2 \times 11$ inches. Provide a separate title page including the following information: title; subtitle; all authors' names and affiliations; and the lead author's full mailing address and telephone number. These items must each be entered on separate lines, double-spaced, using normal capitalization and no underscoring. Each paper must begin with a $100-150$ word abstract.

Tables, figures, and illustrations. Authors are responsible for providing camera-ready copy of tables, figures, and illustrations with the submission of an article. Authors should be prepared to furnish such copy within two weeks after notification by SSLA that their article has been accepted for publication.

References. Brief citations should be made in the text by listing the author's surname, publication date, and page number(s) when pertinent: (Chomsky, 1974, p. 240; Gass, 1973); if more than one, citations should appear in alphabetical order. When the author's name is part of the text, follow this form: Gass (1983) argues that ....

Research referred to in the text must be listed in full in the reference list at the end of each article, review article, or book review following the specifications of the Publication Manual of the American Psychological Association. Begin the reference list on a separate page entitled "References." The references must be doublespaced throughout. Each entry is to include the following: author's name, co-authors (if any), publication date, title of work. For a journal article, also provide the journal's name, volume number, and page numbers for the article. For an article in a collection, list the editor's name, title of the collection, and page numbers of the article. For a book or monograph, list the edition, volume number, series, place of publication, and name of publisher. Punctuate as in the following examples:
Ard, J. (1983). Towards an applied phonology. Paper presented at the Conference on the Uses of Phonology, Southern Illinois University, Carbondale.

Bialystok, E. (1978). A theoretical model of second language learning. Language Learning, 28, 169-183.

Cole, R. A. (Ed.). (1980). Perception and production of fluent speech. Hillsdale, NJ: Erlbaum.

Krashen, S. (1978). The monitor model for adult second language acquisition. In R. C. Gingras (Ed.), Second language acquisition and foreign language teaching (pp. 1-26). Arlington, VA: Center for Applied Linguistics.

Krashen, S., \& Terrell, T. (1983). The natural approach. New York: Pergamon.

Plann, S. (1976). The Spanish immersion program: Towards nativelike proficiency or a classroom dialect? Unpublished master's thesis, University of California, Los Angeles.

Book reviews. Book reviews should be sent to: Susan Gass, Associate Editor, SSLA, English Language Center, 1 CIP, Michigan State University, East Lansing, MI 48824. Begin each book review with a separate title page that includes a full citation of the work under review. The citation is to be double-spaced and must include the title of the work, edition (if not the first), name of the author or editor, place, publisher, date of publication, and pagination. The byline stands below the last text or reference line. It contains the reviewer's name and affiliation on separate lines, flush right. For example:

A FOUNDATION COURSE FOR LANGUAGE TEACHERS. Tom McArthur. New York: Cambridge University Press, 1983. Pp. 192.

Albert Valdman Indiana University

Proofs. First proof of an article or review article will be sent to the lead author (or a nominee), who will be expected to correct and return it to the Editor, by airmail where appropriate, within three days of receipt.

Offprints. 25 offprints will be provided free of charge to the lead author of an article or review article. Additional offprints may be purchased only if ordered at proof stage.

Submission of an article is taken to imply that it has not previously been published or is not being considered for publication elsewhere. If an author is publishing a related article elsewhere, this fact should be stated.

Copyright. Contributors of accepted articles will be asked to assign their copyrights on certain conditions to Cambridge University Press to help protect their material, particularly in the U.S.A. 


\section{Studies in Second Language Acquisition Volume 16 Number 2 June 1994}

\section{COGNITIVE FOUNDATIONS OF SECOND LANGUAGE ACQUISITION}

Edited by Russell S. Tomlin and Morton A. Gernsbacher

\section{ARTICLES}

Cognitive Foundations of Second Language Acquisition: Introduction

Russell S. Tomlin and Morton A. Gernsbacher

Discourse Motivations for Some Cognitive Acquisition Principles

Roger W. Andersen and Yasuhiro Shirai

Analysis and Control in the Development of Second Language Proficiency

Ellen Bialystok

Decision Making in Second Language Acquisition

David Birdsong

Attention in Cognitive Science and Second Language Acquisition

Russell S. Tomlin and Victor Villa

Cognitive Factors in Learning about Structured Sequences: Applications to Syntax

Thomas H. Carr and Tim Curran

Where is Cognition? Emotion and Cognition in Second Language Acquisition John H. Schumann

Reviews

Book Notices

Publications Received 